\title{
Radical Historians and the Liberal Establishment: Staughton Lynd's Life with History
}

\section{Carl Mirra}

"The left presence within the historical profession from the 1960s onward was substantial compared to previous periods," writes Peter Novick in his comprehensive study of the field in the United States. This presence, however, is frequently inflated, as there is "no important historical specialty," in which leftists dominate. Novick concludes that part of the reason why radicals do not command any given historical specialty is that "the ranks of the historiographical left were depleted by the departure from the profession of most of those who had been associated with the [Staughton] Lynd faction of radical historians." Lynd "found other employment," Novick writes, while many "drifted" away. Novick's observation that many radical historians departed the profession in the late 1960s is correct; however, many did not simply drift away. They were forced out. Staughton Lynd, who Novick identifies as the dean of left historians, serves as a case study of the political repression that many historians faced in this time period. A close inspection of Lynd's departure from both Yale University and Chicago State College reveals a complicated tale regarding the treatment of radical and "revisionist" historians in the profession.

Therefore, this paper examines Lynd's academic journey as a study in political repression, suggesting that there was a tendency among US historians to dismiss scholars who fell outside the mainstream center. For example, in 1974 a study by the American Historical Association (AHA) Committee on the Rights of Historians concluded that "the state of academic freedom in the historical profession is poor." The study, known as the Hackney Report, polled 2,200 historians and roughly one third reported that "the political views of a faculty member at their institution influenced judgments of scholarly and pedagogic competence ... there is more tolerance of right-wing than left-wing" perspectives. ${ }^{2}$ Lynd's story presents many difficulties, not the least of which is that there are decent and admirable people on both sides of the divide. My purpose is to establish the degree to which radical historians confronted academic hostility during the late $1960 \mathrm{~s}$, and my findings in no way seek to diminish the work of liberal and other historians who were often hostile toward radical scholars. $^{3}$ In fact, the Lynd case was complicated because his chief academic opponents, to their credit, worked for black equality while questioning the Vietnam debacle. Hence, this essay explores Lynd's academic career at Yale and beyond as a lesson on the broader conflict between radical historians and the liberal mainstream. 
$70 \quad$ Mirra

\section{A Radical Historian meets Yale's Liberal Center}

Lynd seemed destined for a productive and prestigious academic career. Son of the eminent sociologists Robert and Helen Lynd of Middletown fame, he earned a BA from Harvard in 1951 and a $\mathrm{PhD}$ in history from Columbia University in 1962. One of Lynd's professors described him as "just about the best student I have run across." Lynd first gained notoriety in 1964, when he served as director of the Mississippi Freedom Schools, which were part of the broader Freedom Summer campaign that brought together several civil rights groups and a flood of white Northern volunteers. Offered a post at Yale in 1962, Lynd refused as he was in the throes of the Civil Rights movement in the South. Lynd says that he declined Yale's first invitation in part because George Pierson, who hosted his visit to New Haven, "told me not to leave my briefcase in the car at lunch because we were in 'darktown."'s The atmosphere in New Haven differed from Atlanta, where Lynd was teaching at Spelman College, having accepted an invitation from Howard Zinn in 1961 to teach at the black women's college. Lynd remained at Spelman until 1964. By this time Spelman had fired his friend Zinn, and Lynd left for Yale after receiving a second offer from then chair Edmund Morgan. ${ }^{6}$ Lynd was appointed assistant professor of history at Yale in July 1964 on a five-year contract.?

Yale also inaugurated a new president, Kingman Brewster, that year. Brewster was part of what his biographer calls the "liberal establishment," a collection of East Coast intellectuals who were trained in prestigious preparatory schools and Ivy League universities for leadership positions in government and higher education. ${ }^{8}$ Alan Matusow's The Unraveling of America: A History of Liberalism in the 1960s captured the ideological presuppositions of these elite reformers. Liberals supported civil rights and waged a "war on poverty", but "their program contained no hint of radicalism." Radicals called them "corporate liberals" because they had "no desire to stir up class passion [or to] redistribute wealth" as liberal reforms "implied no basic dissatisfaction with the existing capitalist system." Brewster was deeply rooted in the liberal establishment. US President Lyndon B. Johnson appointed him to a presidential commission on the draft. The Yale president was also "best" friends with national security adviser, McGeorge Bundy, a chief planner of the Vietnam War. ${ }^{10}$ In short, Brewster was an "establishment liberal," who might question US strategy in Vietnam or on racism, but not the system that perpetuated war and inequality. ${ }^{11}$

Liberal administrators such as Brewster shared many of the same assumptions of scholars associated with "consensus historiography." Lynd's senior colleagues at Yale were Cold War liberals, more comfortable with "consensus" history than Lynd's unfolding radical scholarship. They were nonetheless impressed by Lynd's scholarship and commitment to civil rights. ${ }^{12}$ The consen- 
sus approach found a trend toward equality among various classes and groups in American history, shrouding what left historians saw as advantaged classes with disproportionate power and influence throughout the nation's history. Under the consensus paradigm, the excesses of McCarthyism were often dismissed in the same breath as the "excesses" of the Civil Rights and antiVietnam War movements. The consensus approach dominated American historiography from the early 1950 s to the mid-1960s. Most scholars agree that the consensus school found its "greatest widespread expression" in Richard Hofstadter's The American Political Tradition (1948); Daniel Boorstin's The Genius of American Politics (1953); Edmund and Helen Morgan's The Stamp Act Crisis (1953); John Morton Blum's The Republican Roosevelt (1954); and David Potter's People of Plenty: Economic Abundance and the American Character (1958). ${ }^{13}$

Potter, Morgan, and Blum were members of Yale's History Department, and the latter two spoke out against Lynd's scholarship and activism. Blum's contribution to the liberal consensus is evident in his belief that President Theodore Roosevelt propelled the nation's "role in maintaining international stability" and "the moral development of its people which constituted the resources for national greatness." 14 Morgan articulated the consensus view that popular movements, or "the mob," lacked agency. In Morgan's view, historical change came from above and great intellectual thinkers drove history. Boorstin solicited Morgan's Birth of the Republic, 1763-1789 for a series devoted to "scholarship opposed to Charles Beard." Beard belonged to the progressive school of history in the early twentieth century, which emphasized the economic conflict between industrial elites and farmers. Consensus history instead promoted the homogeneity and "genius" of the American character, which advanced economic prosperity and liberty. For this reason, consensus history is sometimes called counter-progressive. As Morgan wrote regarding the American Revolution, "the struggle over who shall rule at home was unlikely to bear many of the marks of class conflict." 15 Although consensus historiography was articulated by both conservatives and liberals, its general tenor is inseparable from Matusow's description of liberalism.

When Lynd arrived at Yale, its senior historians had already embraced consensus historiography and liberal anticommunism. Lynd believed that "the big three" at Yale generally fit this pattern and consequently denied him tenure in 1968. The big three included the great C. Vann Woodward, who challenged consensus approaches but grew increasingly conservative and anti-radical throughout his career. The remaining two are the influential Edmund Morgan and John Morton Blum. As Blum explained, "I'm a Harry Truman Democrat," who rejects the "rigid conservatives of Barry Goldwater" and the "doctrines of the New Left." Note that the New York Times declared in 1965 that Lynd was the "elder statesman" of the New Left. For activists this description was a 
badge of honor, but within academia such activist credentials spelled trouble for the young historian.

One reason why the New Left radicals challenged liberalism arose from its knee-jerk anti-communism in the 1950s and 1960s. Lynd resisted the liberal anti-communism of his time, while $\mathrm{C}$. Vann Woodward was associated with the CIA funded, anti-Communist, International Association for Cultural Freedom. ${ }^{17}$ Although we should not overemphasize Woodward's involvement with this organization, his anti-Communist orientation led to a confrontation with Lynd regarding his political engagement, a topic we shall explore. Suffice it to say that Lynd's departure from Yale follows a pattern of political conflict rather than the convenient academic tendency to obscure such clashes as a matter of personal disagreement or lack of "collegiality."18

Lynd was a self-described radical, who the House Internal Security Committee deemed a "radical speaker." Lynd's political self-portrayal differed from Edmund Morgan, who once called himself a "hard-core liberal ... I am not over to the left where 'liberal' is a dirty word, and you have to be a radical, rather than liberal." 19 In short, Lynd's New Left historiography differed sharply from his Yale colleagues. Lynd's scholarship centered on how popular movements during the American Revolution planted the seeds for twentieth century radicalism. Urban craftsman, tenant farmers, seamen, Native Americans, slaves, and women nurtured this vision of a democratic society, which was often more revolutionary than that of the Founders who restricted the degree to which equality would be realized. The Founders were "counterrevolutionary," Lynd argued, as they maintained significant inequalities in property relations and voting rights. Conversely, Morgan credited great men or the Founding Fathers as the originators of egalitarian, revolutionary values. As Lynd pointed out, Morgan suggested that the Declaration "let loose the idea of equality among other social groups." This debate may seem like theoretical hair splitting, but it signifies the New Left emphasis on popular movements as the catalyst for change, while the liberal scholars stressed that the Founding Fathers were the true inventors of America's egalitarian tradition. Simply put, New Leftists promoted a history from the bottom up, while liberal scholars generally took a topdown approach. Morgan dismissed this bottom up methodology as an attempt to "sustain a left-wing opposition to injustice then and now." That is, New Left historians "have compensated for political isolation" by identifying with the downtrodden, in Morgan's view. Lynd countered that New Leftists are hardly insulated from political movements. Lynd, Zinn, and many New Left historians worked at the forefront of the Civil Rights and anti-Vietnam war movements. ${ }^{20}$ It is ironic that Morgan charged the New Left with political detachment as much of their work unapologetically promoted the connection between theory and practice, scholarship and activism.

At the same time, New Leftists aimed to debunk liberalism as an ideology 
and uncover how mainstream scholarship promoted a capitalist consensus. For Lynd, this was not simply a theoretical debate but a conscious attempt to justify the radical movements of his day. Historians routinely chastised revisionist scholars for a lack of objectivity and for distorting the past to serve contemporary, activist impulses. The New Leftists argued that the liberal center was every bit as activist as the New Left methodology. Jesse Lemisch's On Active Service in War and Peace documented this activist trend among mainstream scholars who openly acknowledged that their teaching and writing served the anti-communist crusade. ${ }^{21}$ Lynd's brand of intellectual activism was what most unsettled his Yale colleagues.

\section{Lynd, Yale, and Vietnam}

Lynd arrived at Yale in the same year as the Gulf of Tonkin Resolution and the massive escalation of the Vietnam War. Like many activists at the time, Lynd's attention and energy shifted to the Vietnam conflict. In May 1965, Lynd offered a challenge to both liberal, academic complacency and the class interests that drove the Vietnam War. Lynd announced at the Berkeley Teach-In that:

I am employed by Yale University, the institution which produced the architect of the Bay of Pigs, Richard Bissell; the creator of Plan Six for Vietnam, W.W. Rostow; and that unagonized reappraiser, McGeorge Bundy ... I think I know something about the Ivy League training which these unelected experts receive: a training in snobbishness, in a provincial ethnocentrism, in a cynical and manipulative attitude toward human beings ... [who work toward] defending the general interests of their class ... annihilation in a Brooks Brothers suit is still murder. ${ }^{22}$

Such comments were probably not well received in New Haven. In print, these remarks lack what Todd Gitlin calls Lynd's gentle cadence and "sweet" temper. This speech revealed the major cleavage between Lynd and his liberal colleagues. Lynd committed the sin of questioning the class interests behind the Vietnam conflict. He consistently challenged the master narrative of American history, or the overall historical interpretation that glorifies America's individual rights preserved under the system of democratic capitalism. As that grand narrative goes, abuses and transgressions may exist, but capitalism remains the best system for the advancement of liberty, prosperity, and democracy. Under this framework, the Vietnam War is seen as a failed attempt to spread democracy, rather than a crude expansion of global capitalism. "It is not the absence of democracy that offends our governing class," Lynd argued at a conference in 2005, "it is the interference with private capital, which that class considers the indispensable precondition for democracy." 23 This formulation resembles 
socialism and borders on heresy as it directly confronts the grand narrative. Capitalism, some radical historians argue, is not necessarily compatible with democracy and anyone who questions this narrative "must confront the massive indoctrination" that suggests "socialism and democracy are incompatible." Throughout his own career, Lynd has continued to challenge what he calls a "devotion to capitalism," because "the deeper purpose of American socialism has always been the completion of the American revolution." ${ }^{24}$

In the $1960 \mathrm{~s}$, Lynd transformed such scholarly observations into action. He chaired the first march against the Vietnam War in Washington, DC on 17 April 1965. It seemed as if "nothing could have stopped that crowd from taking possession of its Government," Lynd recalled, "perhaps next time we should keep going." 25 Lynd joined another march on Washington against the war in August 1965 in which 1000 protestors marched on the capital. A photograph of Lynd along with David Dellinger and Robert Moses drenched in red paint that was tossed on them by American Nazi party counter-demonstrators appeared in Life magazine. ${ }^{26}$ John Morton Blum's recollection of this event during an interview in 1992 signified the wide chasm between liberal and radical scholars. Blum, who served as Yale's History Department chair during Lynd's term, remembered that activists of the $60 \mathrm{~s}$ "reached the point where they were mad, not in a clinical sense but in an emotional sense - excessively emotional ... not subject to rational discourse about either urban racial issues or/and the war in Vietnam ... That photo of Lynd with blood across him and his arm raised really represents the mood he had cultivated within himself.,"27 Blum's recollection is interesting: the right-wing extremists who threw paint at Lynd and his fellow protestors were also, surely, "excessively emotional." Moreover, the photograph in Life Magazine does not show Lynd with his arm raised. ${ }^{28}$

Both Lynd and Blum opposed the Vietnam War. The radical Lynd understood the Vietnam War as the natural consequence of imperial expansion. The more reserved Blum considered it a "tragic mistake," a misguided attempt to spread the "promise" of America abroad..$^{29}$ Consider that Blum wrote in his The Promise of America (1965) that, "This inquiry intends to obscure no blemishes, but it does endeavor to rejoice, to describe those patterns that disclose- even for the impatient, perhaps especially for them - the nobility and magnificence of the United States." ${ }^{\text {"30 }}$ Lynd, like many radical historians, grew "impatient" with American power in the late 1960s. Massacres at My Lai and the malevolent napalm sprayings across Vietnam coupled with the murders of Civil Rights workers in Mississippi engendered a sense of "impatience" among countless Americans. Lynd was not alone in pointing out America's false promise of progress, while liberals emphasized the nation's magnificence. 


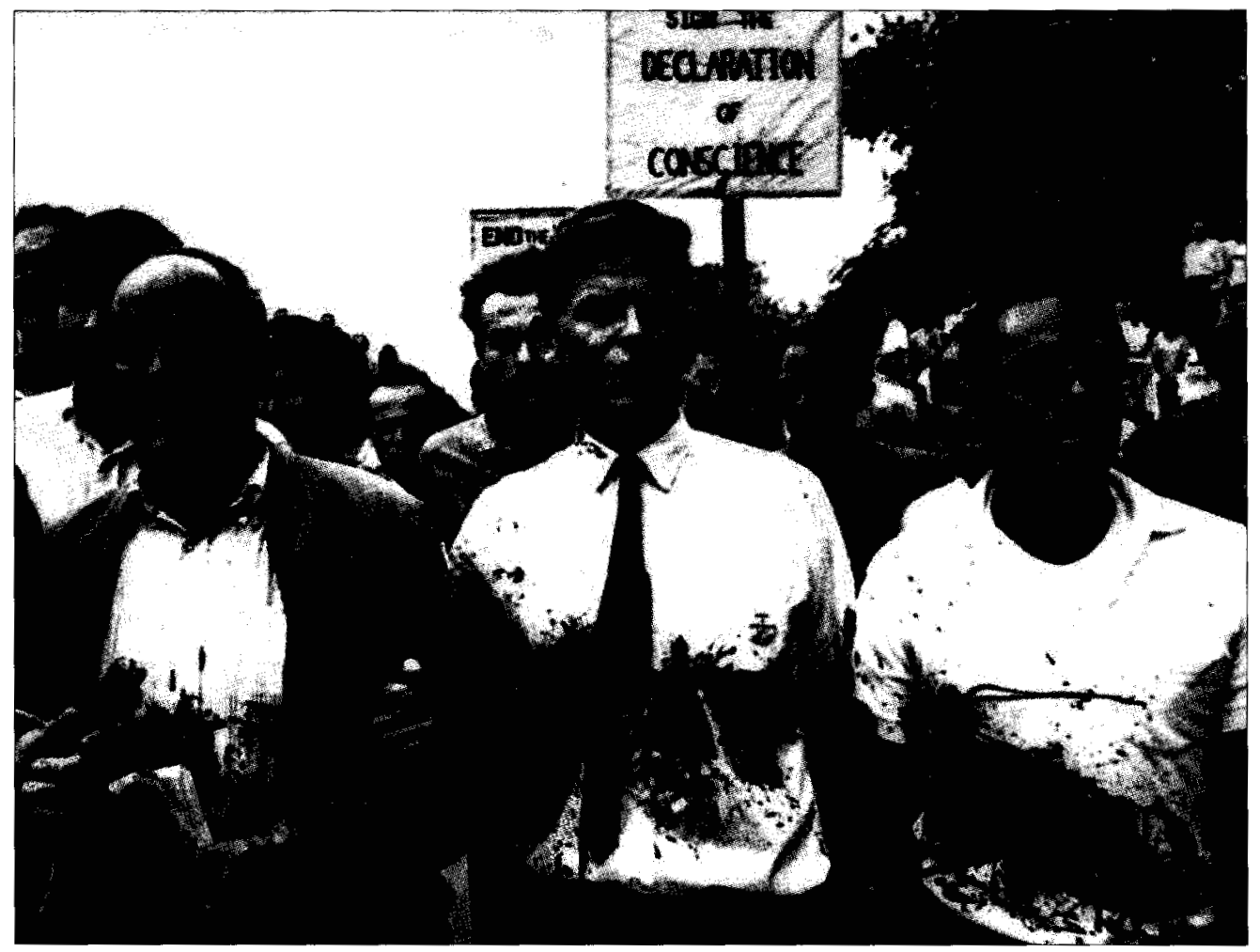

Dave Dellinger, Staughton Lynd, and Robert Moses in the 1965 March on Washington against the Vietnam War. A nearly identical photograph appeared in LIFE magazine, where Lynd appeared calm and without his fist in the air. 


\section{Yale, America's Promise, and the Civil Rights Movement}

C. Vann Woodward, one of Lynd's colleagues at Yale not entirely inebriated by America's magnificence, was occasionally seduced by the lure of US progress, given his burgeoning anti-radicalism. Lynd's ideas regarding the black freedom struggle clashed with Woodward's sensibilities. Before Lynd arrived at Yale, he had worked as a volunteer with the Student Non-Violent Coordinating Committee (SNCC) during Freedom Summer in 1964. Lynd's affiliation with SNCC prompted Woodward to write him in 1965 to "learn all I can about the movement." What Woodward learned from reading newspaper reports was that, "alarmists" may "have exaggerated the Communist infiltration of SNCC, but I am persuaded that they are present and active in it." SNCC, Woodward opined, was "treating the Communist question too lightly." did little to relieve his concerns. The young professor said, "Of the hundreds of persons who have been on the SNCC payroll, a few have been former members of the Communist [party] ... although I know of no such cases." Lynd concluded, "If you can do the work, we ask no other questions." ${ }^{2}$

It was true that SNCC had an open membership policy and that some members had once been associated with Communist groups. However, the organization's focus on voter registration and its refusal to follow any single ideology was at variance with Marxist dogma. Clayborne Carson's exhaustive study of SNCC, In Struggle: SNCC and the Black Awakening of the 1960s, finds little Communist influence in the organization. He cites FBI files that failed to connect SNCC with any Communist group between 1964 and 1967; an August 1967 Bureau investigation states that, "Communists are not known to have gained any national leadership positions in SNCC to date."33 Despite the absence of evidence, the reckless J. Edgar Hoover publicly accused SNCC of Communist infiltration.

Woodward's assessment of SNCC in 1965 is closer to Hoover's than the historical record. It is understandable that the liberal Woodward would view SNCC with suspicion as the media often incited fears of the group. Woodward acted on this trepidation and advised Lynd, who was his untenured junior colleague at the time, that, "the leaders [of SNCC] could make a firm disavowal of communism ... and you would do a service to the movement by so persuading them." The difference in political orientation between Woodward and Lynd in this exchange was obvious: significantly, Woodward directed Lynd to take corrective action against an imagined communist infiltration. Whatever one may conclude about Woodward and his heroic defense of Angelo Herndon in the 1930 s, what this conversation revealed was a liberal scholar engaged in antiradicalism by the mid-1960s. ${ }^{34}$

Perhaps Woodward was correct to identify SNCC as a radical group, but he exaggerated its dependency on communists. Historian Manning Marable sheds 
light on why SNCC gradually evolved into a more radical organization. In the Mississippi Freedom Summer project, over 1000 African Americans were arrested, 6 were murdered and 36 black churches were bombed or burned. White supremacist assaults on blacks persisted throughout the South. Like the Vietnam protestors, civil rights workers also grew "impatient" with America's promise of progress. Given this violent milieu, Marable concludes that many African-Americans saw the limits of reform, a perspective that was difficult for white liberals to comprehend. He points to C. Vann Woodward as paradigmatic of white liberals who failed to properly grasp the situation. Woodward wrote in his seminal work, The Strange Career of Jim Crow, that, "blacks had no more obstacles to confront ... American institutions were responding effectively to the most serious domestic problem the country faced. Jim Crow as a legal entity was dead." With "an administration thoroughly committed to the cause, a new era of progress was about to come." In this instance, Woodward's anti-radicalism found expression in the liberal vocabulary of progress. Marable concludes that black activists, including SNCC workers, simply could not accept Woodward's "gross misconception." 35

Rather than persuading SNCC to denounce Communism, Lynd argued in the Intellectual Origins of American Radicalism that the group's leaders articulated "the logic of the preamble of the Declaration of Independence." Lynd further defended SNCC in a New York Times article, "A Radical Speaks in Defense of SNCC." Lynd saw little reason to reduce SNCC to a rabble of communist dupes, and instead placed them alongside a long tradition of American radicals, who acted on the words in the Declaration of Independence and "the revolution that it justified." ${ }^{36}$ The rising young scholar turned historical inquiry on its head by linking familiar American traditions to contemporary radicalism.

Woodward's "gross" miscalculation regarding both black gains in the South and his belief that communists infiltrated SNCC stand in stark contrast to Lynd's scholarly writings. In Intellectual Origins of American Radicalism, Lynd argues:

Both the NAACP and SNCC derive from W.E.B DuBois' seminal essay "Of Mr. Booker T. Washington and Others" that ended with an appeal to "those great words which the Sons of the Fathers would fain forget": the preamble of the Declaration of Independence. The most militant Afro-Americans in the 1960 s, similarly, still refer to a "law higher than the law of government" and the conflict between "property rights" and "human rights" as did earlier revolutionaries.... For almost two hundred years all kinds of American radicals have traced their intellectual origins to the Declaration of Independence and the Revolution it justified. They have stubbornly refused to surrender to liberalism or reaction, insisting that only radicalism could make real the rhetoric of $1776 .{ }^{37}$ 
$78 \quad$ Mirra

\section{Lynd's Activist Scholarship}

When the Yale History Department denied Lynd tenure in March 1968, they approved of much of his work. But, "when the department turned to the Intellectual Origins of American Radicalism," a letter from then chair Howard Lamar to Lynd states, "it was agreed that this latest scholarly evidence considerably weakened the case for your promotion and also reduced any chance we might have of securing an incremental tenure position in American history for you." ${ }^{38}$ Did Lynd's attempt to link black radicals to the principles of the American Revolution offend the anti-communist political leanings of Lynd's superiors?

Consider that the Journal of American History described Intellectual Origins as a "strong" book that tackles cycles that "are seldom mentioned in our histories." ${ }^{39}$ Eugene Genovese offered a far different review of Lynd's work. In the September 1968 issue of The New York Review of Books, Genovese reviewed Lynd's Class Conflict, Slavery and the U.S. Constitution and Intellectual Origins. He classified Lynd as an "ideologue of the New Left," whose "glorification of the common man" hides Lynd's "contempt for and distrust of the intelligentsia." Before this review appeared, Woodward wrote to the Yale History Department chair in April 1968 to alert him about Genovese's review that is "in press."

The substance of Genovese's critique concerned what he classified as Lynd's anachronistic claim that the Founders failed to abolish slavery in the age of revolution. Lynd countered that the Founders themselves repeatedly condemned slavery, while England abolished it before the American Revolution. It was hardly out of time and place to raise the moral issue of why the Founders failed to end slavery in 1776, especially given their allegiance to an ideology of liberty and equality. The Founders could not envision a genuine equality between black and whites, Lynd maintained, because they feared that an attack on slavery's private property might lead to an assault on bourgeois property. Hence, the Founders advanced a revolutionary ideology that reflected their social and economic world. Years later Gary Nash, the historian who served as the president of the Organization of American Historians in 1994-5, concluded that, "The weight of scholarly work in the last several decades is decidedly on Lynd's side of the issue." Indeed, Lynd's "work as a historian was impeccable," Howard Zinn opines, "and there was no rational basis for denying him tenure on scholarship grounds." Harvard University Press also thought highly of Intellectual Origins, republishing it in 1982.41

In 1968, Commentary magazine offered a more balanced review than Genovese, suggesting that Lynd's aim was to "strip the complacent façade of American society," to reveal "the intense class and racial struggles that have gone on behind this apparent consensus." Hence, Lynd's "careful research" in 
this "major work" is "proof that social involvement can sharpen rather than blunt a historian's perceptions." "42 Genovese, a Marxist, was nonetheless a hostile critic of New Left historians, especially Lynd. He once wrote Woodward complaining about "the fellow-traveling scum who peddle their asses on street corners." ${ }^{43}$ We should not confuse Genovese's Marxism with left activism; he is a bitter and obscene critic of radical historians. Genovese's Marxism was not a device for social change, but was limited to historical analysis. ${ }^{44}$ Conversely, Lynd was foremost among the radical historians in following Marx's eleventh

Theses on Feuerbach: "the philosophers have only interpreted the world ... the point is to change it." It would be a mistake to reduce Lynd's scholarship to mere activism; it was an attempt to provide a historical foundation for the participatory politics of the New Left. Lynd's work was critical research on praxis, which was no less rigorous than traditional historiography. Genovese's scholarship presented Southern planters as an alternative to bourgeois capitalism, an argument that utilized Marxist theory, but it was far from the New Left historians who wrote history from the bottom up. In 1965, Genovese wrote that antebellum "Southern ideals constituted a rejection of the crass, vulgar inhumane elements of capitalist society." The "ideals" of Southern slave society offered an alternative to capitalism in Genovese's view, a perspective that differed sharply from Lynd's belief that "the proper foundation for government is a universal right or wrong self-evident to the intuitive common sense of every man." Lynd's sympathy rested with ordinary people, whereas Genovese developed a fondness for Southern planters. ${ }^{45}$

At the very moment that Yale dismissed Lynd in 1968, it recruited Genovese for a visiting scholar position. The department chair, Howard Lamar, acknowledged the "administration's quandary" given the Lynd matter and "would understand" if it decided against the Genovese appointment. Yale eventually approved Genovese for a visiting position and Woodward offered him office space. ${ }^{46}$ Equally interesting is that another reason for Lynd's expulsion concerned "budgetary constraints," but this restriction did not prevent the appointment of Genovese. ${ }^{47}$

\section{Timeline to (un)Tenure: Yale Alumni and the Mission to Hanoi}

Lynd's troubles with academia started in December 1965, when he embarked on a journey to North Vietnam with the Marxist historian Herbert Aptheker and activist Tom Hayden. Complications began for Lynd immediately upon his return. Yale president Kingman Brewster, Jr. released a formal statement on 18 January 1966. On the one hand, Brewster defended Lynd's right to free speech. On the other, he chastised Lynd for commenting in Hanoi that the Johnson administration lied to the American people. Such statements, Brewster felt, "give aid and comfort to a government engaged in hostilities with American 
forces ... this irresponsible action ... has done a disservice to the causes of freedom of dissent, freedom of travel, and conscientious pacifism."

Documents at the National Security Archive confirm Lynd's charge. It is now known that the Johnson administration deceived Congress and the American people on several occasions, most notably in August 1964 during the Gulf of Tonkin incident. The Johnson administration maintained that communist North Vietnam launched an "unprovoked attack" on the USS Maddox on 2 August 1964. The attack was hardly unprovoked; declassified documents illustrate that the US coordinated, and participated in, raids on the North before the August 2 encounter. Worse yet, the Johnson administration reported a second attack on August 4-one which probably never occurred-and which ultimately led to a Congressional resolution that escalated the Vietnam War. On August 4, the morning of the alleged second attack, Defense Secretary McNamara told President Johnson that, "this ship is, uh, to be attacked tonight." Before the matter went before Congress, National Security Adviser McGeorge Bundy wondered if there was sufficient evidence to confirm the August 4 attack. One staff member then asked if the Congressional resolution should be delayed until more concrete evidence was collected. According to the National Security Archive, "Bundy, in reply, jokingly told him perhaps the matter should not be thought through too far ... he welcomed the recent events as justification for a resolution the administration had wanted for some time." ${ }^{49}$ Bundy operated in defense of the general interests of his class, precisely as Lynd had charged in his 1965 Berkeley address. Both Bundy's willingness to cooperate in spite of the sketchy data and Johnson's exchange with McNamara confirm Lynd's belief that the administration deceived the public. Just as the Johnson administration rushed to judgment in the Tonkin affair, Brewster quickly berated Lynd as disloyal.

Yale alumni, who were collectively to the right of Brewster, expressed similar attitudes. William Buckley, Jr. clarified that Lynd was not technically guilty of treason for traveling to Hanoi; however, if legal sanctions did not apply, Buckley wondered, "Will the social sanctions be forthcoming?"s0 A flood of angry letters poured into Brewster's office following Lynd's Hanoi trip, pressuring Brewster to take action against the dissident scholar. An agent of the Yale alumni fund wrote Brewster on 21 January 1966, saying, "Professor Lynd has brought nothing but disrepute on the Yale name." Alumni were already outraged regarding the university's granting of an honorary degree to Martin Luther King, Jr., a "great blot on Yale from which it will take a long time to recover." Lynd's recent actions presumably hindered this recovery, the agent intimated, writing that, "I am certainly being put on the spot by my classmates in the raising of funds." Finally, the agent asked if there was something that the Yale alumni could do to remove Lynd from the faculty. ${ }^{51}$

A letter provided by one alumni fund agent to another suggested an action 
that alumni could take to remove Lynd. "The university depends mightily on graduate financial support ... your thinking has an indirect effect on policy," the letter noted, "We have a duty to express our opinion, and your contribution entithes your ideas as well as your money to be taken into account." 52 These opinions included making it clear that it was "unthinkable" that Yale "should retain a man who is avowedly a Marxist employing Communist dogma." What was most troubling was that "we are expected to pay the salaries" of educators such as Lynd. Yet another alumnus asked, "How can we expect our sons and daughters to become good American citizens after four years of brainwashing by such scum as exemplified by Lynd?"s3

This ardent campaign among alumni to fire Lynd was acknowledged by one important fundraiser. In early February 1966, the Alumni Fund chair, John Castles, informed Brewster of "the great many inquires" from alumni regarding Lynd's "antics." Castles had drafted a form letter to alumni explaining that Lynd's actions were "indefensible," and "the matter is complicated by the international implications of the Hanoi jaunt." It was unfortunate, the letter continues, that Lynd has "abused his association with Yale to further his own political interests. ${ }^{.54}$ Brewster replied to these inquires, stating that Lynd was a fine teacher and entitled to free speech. But he closely monitored the situation, walking a tightrope between empowering Lynd and angering alumni. Consider that Brewster told Castles that, "I never know what the next moment will bring with our fellow traveler ... I do not want to give Mr. Lynd the political benefits of seeming academic martyrdom."ss

In April 1966, perhaps under great pressure from alumni, Kingman Brewster consulted Blum concerning Lynd's professional responsibilities. Blum examined whether or not Lynd missed any of his scheduled classes, but determined that Lynd had not missed any sessions. Were less "political" professors subject to the same examination over duties and obligations? Blum also addressed Lynd's "Ottawa Speech" in March 1966. A US Ambassador to Canada, who was a Yale alumnus, was upset by the speech and sent it to Brewster. In this speech, Lynd claimed that the US "peace offensive" in Vietnam was as deceptive and misleading as Germany's propaganda in World War II. "I took the liberty of telling Lynd," Blum reported to Brewster's assistant, that "his public performances had been strident and extreme, but I rendered that as a strictly personal, not Chairman's opinion." Lynd replied to Blum by quoting a conservative Canadian Member of Parliament, who described the speech as a "factual and sober approach." Blum was unable to report any professional failures on Lynd's part, so he relayed his "personal" feeling that Lynd was extreme and strident. ${ }^{56}$ That Blum offered this opinion to the university administration asking about Lynd's performance surely removes it from the category of "personal" opinion. ${ }^{57}$ James Green, who served on the Yale graduate student committee that investigated the Lynd affair in 1968, sheds light on 
Blum's view of Lynd as strident. Writing years later, Green stated that:

The [Yale] history department voted to deny Lynd tenure, ostensibly for academic reasons. Like Lynd, we thought the decision reflected political animus. The department chair said that Lynd's protest against the U.S. war effort in Vietnam was 'too strident' ... our intervention in the Lynd case was fruitless. ${ }^{58}$

To be sure, Lynd's chair viewed him as "strident and extreme" at a time when alumni were demanding his removal. As President Brewster gathered these opinions, he also understood the hazards of discarding Lynd. Since even the acerbic Buckley grasped that Lynd had not violated the law, Brewster worried that terminating Lynd might rally people against Yale-- the liberal president was not about to crucify a renegade scholar. In the fall of 1967, these concerns prompted Brewster to contact Yale's Treasurer, John Ecklund, requesting a list of attorneys. Ecklund sent a roster to Brewster, noting that, "What is said in Yale's deposition will be usable in Lynd's suit against Yale if he brings one if he doesn't get a contract or appointment." ${ }^{\prime 9}$ Did Brewster consult a lawyer because he believed that denying Lynd tenure would be improper and perhaps illegal?

Brewster's interest in legal advice likely arises from a situation that developed in Chicago. Lynd departed New Haven in June 1967, after Yale made it clear that he almost certainly would not gain tenure. ${ }^{60}$ Since it was made clear to Lynd that his career at Yale would end at the conclusion of his five-year appointment in 1969, he sought employment elsewhere. Chicago State University offered Lynd an associate professorship in history, an offer that was abruptly rescinded by the Illinois Board of Governors of State Colleges and Universities on 17 July $1967 .{ }^{61}$ Chicago State University President, Milton Byrd, confirmed Yale's early view of Lynd's scholarship, describing him as an "historian of prodigious and imposing scholarly productivity," who was a "talented" teacher. Moreover, a group of Lynd's students said that he was "a fine scholar" and few students are fortunate enough to "encounter a teacher of Lynd's caliber."62 Despite these flattering assessments, the Illinois Board of Governors of State Colleges and Universities overturned the Chicago State offer because of Lynd's "public activities." Lynd's actions, the Board argued, moved "beyond mere dissent." The College Board did not dismiss Lynd for any scholarly deficiency, instead citing his radical politics and controversial trip to Hanoi as contributing factors in its decision. ${ }^{63}$ Lynd was denied appointment at four other Illinois colleges in the late 1960s. As historian Alfred F. Young puts it, "Lynd was blacklisted."

Lynd challenged this brazen violation of his rights and filed a lawsuit during the summer of 1967 and he eventually obtained a favorable settlement. ${ }^{65}$ The Yale Daily News noticed the unfolding drama in Chicago. One columnist wondered if "the narrow-mindedness displayed by the Illinois Board of 
Governors and State Colleges and Universities-so easily dismissed as Midwestern provincialism-does not find its counterpart here under the guise of a smoothly-run establishment." 66 Yale's president described Lynd's politics as traitorous; its History Department chair called him strident, while Yale alumni clamored for Lynd's removal. Is it not reasonable to assume that these political denunciations influenced Yale's decision to deny Lynd tenure?

\section{Timeline to (un)tenure: Budget constraint or new calculus?}

Political radicalism was the reason that the Illinois Board provided for dismissing Lynd, but Yale offered a wholly different reason. The exchange between Brewster and Ecklund regarding the possible legal ramifications of dismissing Lynd occurred on 28 September 1967, after the Chicago case was public knowledge. That same day, John Blum disclosed to the Yale Daily News the reason why Professor Lynd should not expect tenure at Yale. Blum stated that the chances for junior faculty in US history to gain reappointment were "miniscule" because of budget constraints. ${ }^{67}$ This report was based, in part, on a 10 September 1966 letter from Lynd to Blum. Lynd wrote that Yale "has informed me that, for budgetary reasons, I should not expect to be rehired when my present five-year contract expires." Lynd then added, "If there is anything in the statement which you believe to be inaccurate, I would appreciate your letting me know within the next day or two." ${ }^{68}$ Blum replied three days later, but did not deny Lynd's understanding of the financial constraints on his reappointment. Instead, the chair noted that, "If nothing were to change, as I said to all of you in American history, your chances for remaining at Yale beyond your current contracts would be miniscule."'69 Blum pointedly informed the young historian that "financial considerations" made tenure highly unlikely.

A rather curious discussion of this budget matter appears in Blum's memoirs, $A$ Life with History. He says that, "a group of graduate students looked into the whole Lynd saga. They found me not guilty of any harassment. But they also concluded that the decision to deny Lynd tenure had no basis in budget stringency. In that they were correct, for just after I left the chairmanship, Yale subjected the budget to a new calculus [italics mine]." In keeping with a recommendation of the Ford Foundation, Kingman and the Yale Corporation agreed to spend annually a portion of the endowment's unrealized gains. This risky adventure in academic finance eased the budgets of all departments." Nearly 40 years after the Lynd debacle, Blum now says that the budget constraint had nothing to do with Lynd's tenure denial.

We must compare Blum's latest account to his public announcement regarding the budget restriction on 28 September 1967 to the Yale Daily News. The significance of this most recent revelation depends on two factors. The first concerns whether or not the new "calculus" occurred before Lynd's tenure 
decision; the second involves whether or not Lynd was expressly informed that the budget was now available for his reappointment. As for the timing, it appears that the budget restriction was lifted six months before Lynd's tenure case in March 1968. Again, the report in the Yale Daily News on 28 September 1967 calls Blum "the former chairman of the history department." By Blum's account, the new budget appeared "just after I left the chairmanship," so at the time of this article Blum very likely was aware of this "new calculus" as his chairmanship ended on 30 June 1967..$^{12}$ Yet, in the same article-"Blum says Lynd's Chances Miniscule because of Budget"-Blum broadcasts that junior faculty in the department will not be appointed "barring an act of God." 73 To be sure, if we follow Blum's account, he might have known of the new budget at the same time that he told Lynd and others that the budget prevented them from gaining tenure. Here was Blum's opportunity to clarify that the budget restriction no longer applied, or at least would soon drastically change. Instead, he announced that it would require divine intervention to surmount the budget situation. And, in stark contrast with Blum's certainty that there would be no new positions, the new budget led to a "series of grand appointments," including Americanist David Brion Davis shortly thereafter. ${ }^{74}$

As for informing Lynd of the new calculus, the History Department claims that he was repeatedly told, while Lynd maintains that he was not informed of this new financial possibility. The whole affair was unleashed in the pages of the Columbia University Forum. Lynd's contentious article, "Academic Freedom: Your Story and Mine," appeared in the fall 1967 issue of the Forum, enraging his colleagues in New Haven. Lynd wrote that:

Members of the History Department have shown me considerable decency and kindness. But I believe they have also been under pressure and that, when push came to shove, they have chosen to protect Yale rather than me ... Professor Blum moved with the institution from neutrality to condemnation ... he told me that I should not expect to receive tenure when my appointment as an assistant professor ended. I was on the eve of a Morse Fellow during which, ordinarily, a junior professor does that work on the basis of which (at least in part) his candidacy for tenure is evaluated. The date was April 1966; my contract ran to 1969 , and the department would not formally make its decision on tenure until 1968. Nevertheless, Professor Blum chose this moment to tell me not to expect promotion. ${ }^{75}$

Edmund Morgan and C. Vann Woodward responded in the spring 1968 Forum issue. "One of us conveyed personally and repeatedly to Mr. Lynd ... that the chances of promotion were not as dismal as they seemed in the spring of 1966, that somehow by 1969 more money would be found."' Yale Daily News that Lynd's chances were miniscule due to the budget contradicts Morgan and Woodward's position. 
Letters in the Kingman Brewster archives at Yale also contradict Morgan and Woodward's assertion that Lynd was informed that he still might gain tenure in the fall 1967. One such letter, dated 18 October 1967, from Brewster's special assistant to John Seifert, states that Lynd had been warned that "a tenure position is not likely."' These conflicting accounts clearly illustrate that Lynd was not given fair consideration for tenure, based on scholarly considerations alone. $^{78}$

To the best of my knowledge, an external and objective peer review of Lynd's scholarship was never performed. Instead, the History Department's formal reasons for Lynd's termination center on two main concerns. The first reason Yale offered to Lynd was that his scholarship was weakened by the publication of the Intellectual Origins of American Radicalism, which somehow diminished a scholarly record that included three other books. James Green points out that the book "is not really representative of Lynd's historical writing, past or present." $"$ A critical review in a leading historical journal still determined that Intellectual Origins is "nevertheless strong."

Equally significant is that the graduate student committee also felt that "on the basis" of Lynd's publications and teaching ability he qualified for an appointment. Yet, in January 1968, the graduate student investigators sent Lynd a letter, signed by James Green, stating that, "we did not detect any political animus [from the History Department] toward you on their part ... and do not believe ... that any existed." Lynd immediately replied that it would be "more scrupulous" to say that no evidence of political animus exists as opposed to noting that "we do not believe." "Green, who describes C. Vann Woodward as his mentor, later revealed that, "It was a kind of superficial investigation ... the department didn't let us see the letters." In fact, "We were sobered by the price [Lynd] had paid for his political convictions," Green concluded. ${ }^{82}$

These political convictions evidently overshadowed Lynd's scholarly record. Yale initially maintained that he was hired on the "basis of his outstanding scholarship." An undated form letter in Brewster's papers states that, "Lynd has satisfied the exacting requirements" as defined by the Yale committee on tenure. ${ }^{83}$ In 1966, these positive assessments were again confirmed when Yale awarded Lynd a Morse fellowship for his "fine teaching" and "scholarly promise." ${ }^{84}$ By the time of Lynd's tenure decision, Yale's praise for Lynd suddenly evaporated. Influential scholars, however, continued to laud Lynd's scholarship in spite of Yale's sudden change. Celebrated English historian E. P. Thompson wrote a favorable preface for Lynd's Class Conflict, Slavery and the United States Constitution. ${ }^{85}$ Edward Countryman, Distinguished Professor of History at Southern Methodist University and winner of the prestigious Bancroft prize, considered Lynd's studies of the American Revolution among the "high points" in the field. It was Lynd and fellow scholar Alfred F. Young who "launched the contemporary study of working people in the revolutionary era." ${ }^{" 16}$ Perhaps this 
whole saga is best summarized by Robin Winks, who was a member of Yale's History Department at the time of Lynd's dismissal and served as chair in the late 1990s. "He was a good historian," Winks noted, "his work was wellregarded." The problem for Lynd was that he was "in the eye of the hurricane," Winks recalled, "he had much more courage than I did, though I was opposed to the war also ... he put his money where his mouth was." ${ }^{87}$

The second reason that the Department offered for Lynd's discharge was the "problem of your personal relationships with the Department." It seems that Yale did not welcome a scholar who put his money where his mouth was. The History Department told Lynd that they were "stunned" regarding his public comment that "for political reasons the Department and the Yale administration" had denied him tenure ${ }^{88}$ Remember that the History Department chair privately reported to the university president that Lynd was "strident" at a time when alumni were aggressively calling for Lynd's removal. In both the political and professional arena, Lynd "put his money where his mouth was" and for the outspoken Lynd it meant cashing in his academic career.

\section{Life after Academia}

In the immediate aftermath of his firing, Lynd aimlessly walked the streets of New Haven in tears. Lynd had nowhere to go as he was banished from academia; he was literally lost without an occupation to call his own. Lynd had three children at the time and turned to his wife, Alice, to support the family. Alice worked for a while as a counselor for Vietnam draft resisters. In 1973, Lynd entered a new career, starting law school at the University of Chicago. Both he and Alice attended law school and gradually reinvented themselves as labor lawyers, settling in Niles, Ohio, a steel town outside of Youngstown. Lynd, who became a Quaker in 1963, continues to embrace the life of the "organic intellectual," someone who aids ordinary, oppressed people in their struggle for equality. His legal skills are tools in the working-class struggle for better working conditions. Living among the working-class in Ohio, Lynd practices what his friend and fellow historian E. P. Thompson called "agency," or what Marxists simply view as uniting thought and action. Although he has discovered meaningful work in a small steel town, Lynd nevertheless refuses to surrender the master narrative of American civilization to the establishment. Too often radical historians are encouraged to "stay away from overall interpretation," Lynd bemoans, "We who accompany the poor in their tribulations, like those we study, must know our proper place." But, "we confront a big system whose advocates think in the large and have a long-term trajectory" so we must avoid surrendering "to our more conservative colleagues issues of overall interpretation." ${ }^{89}$ 
Lynd paid the price for challenging the grand narrative without the usual protection of tenure. Many US revisionist historians also paid for "putting their money where their mouth was" by questioning the master narrative of American history during the 1960s. The eminent, revisionist scholar William Appleman Williams was called before the House Un-American Activities Committee in 1960. Howard Zinn was fired by Spelman College in 1963 and even Eugene Genovese confronted academic difficulties following a favorable public statement about North Vietnam. New Left historian Jesse Lemisch, who demanded a "history from the bottom up," was rejected by the University of Chicago in 1966. He was told by a senior colleague: "your convictions interfered with your scholarship." In other fields, the Radical Sociology Movement finds that some 200 radical scholars were terminated or blacklisted in the late 1960s and early 1970s..$^{90}$ In brief, Staughton Lynd's political discrimination in academia was part of a pattern of political and social harassment of outspoken left historians. We should not overstate this pattern of repression; we should not downplay it either. ${ }^{91}$

\section{Aptheker at Yale: A postscript on Lynd and the Liberal Establishment}

A most instructive example of this tendency concerns Herbert Aptheker, the Marxist historian who invited Lynd to Hanoi in 1965. The Yale scholars who denied Lynd tenure orchestrated a "massive attack on a minor appointment" following an invitation to Aptheker to teach one-semester seminar at Yale as a Visiting Lecturer in 1975. ${ }^{92}$ Yale's Davenport College invited Aptheker to teach a residential college seminar on W. E. B. DuBois. Aptheker, who held a PhD in History from Columbia University, was the literary executor of Dubois' papers and author of roughly 30 books.

After approving the proposal for Aptheker as a single semester lecturer, Davenport College was required to obtain a departmental sponsor. They requested sponsorship from the History Department, which established a subcommittee to consider the Aptheker proposal. The committee included C. Vann Woodward, John Blum, and John Blassingame, who rejected Aptheker's appointment without a departmental vote. ${ }^{93}$ Woodward insisted that Aptheker's scholarship was not "up to our standards." This stance was a rather ironic considering that fellow subcommittee member John Blassingame repeatedly cited Aptheker's work in his text, The Slave Community. Eminent historian John Hope Franklin also approved of Aptheker's work on slavery, while Sterling Stuckey described his edited collection on DuBois as "an indispensable source of information." "94 The Black Student Alliance at Yale agreed with these expert opinions and angrily derailed the History Department for rejecting a professor with "impeccable credentials," which "reveals their real intention: to strictly bar diverging scholarly and intellectual viewpoints." 
Department derailed a radical teacher, maintaining that Aptheker did not measure up to Yale's standards. ${ }^{96}$

After the History Department's rejection, the Davenport College Committee turned to the Political Science Department for sponsorship. This department unanimously approved Aptheker's temporary appointment, explaining that the standards for visiting instructors differ from that of regular appointments. Over 1000 Yale undergraduates signed a petition in support of Aptheker's appointment. Critics were quick to point out that journalists, cartoonists, and photographers routinely taught college seminars, while Jesse Lemisch circulated a biting essay, "If Howard Cosell can teach at Yale, why can't Herbert Aptheker?" Following the Political Science Department's endorsement, the Aptheker seminar was brought to the Joint Board of Permanent Officers for approval. Approximately 40 professors appeared for the vote, and roughly 10 of them were from the History Department. Woodward and Blassingame each presented statements against Aptheker's appointment. The Joint Board voted overwhelmingly against Aptheker, the first seminar to be overturned by the board. "Why does the first seminar appointment to be rejected," a Yale professor wondered, "happen to be that of a prominent American Communist?"פ? Indeed, it is rather odd that this unprecedented action was taken against a left scholar.

The pugnacious Aptheker fired back. "Being victim to similar attacks during the McCarthy era," Aptheker thundered, "I knew immediately ... the problem was my Communist Party affiliation. ${ }^{98}$ He filed a formal complaint with the Organization of American Historians. In an unprecedented move of a different sort, the historian's group voted to investigate Aptheker's charges against the History Department, the first time the organization conducted such an investigation. ${ }^{99}$ A joint committee of the American Historical Association (AHA) and Organization of American Historians Committee on the Defense of the Rights of Historians was soon established. As the investigation lingered, the DuBois seminar was approved in April 1976 under sponsorship from the Political Science Department and held during the fall of 1976. The heated controversy gradually cooled down. The joint committee eventually exonerated the History Department, releasing a formal statement on 27 December 1977 at the American Historical Association's annual meeting. ${ }^{100}$

However, the issue was not entirely resolved. For one thing, the Yale History Department never released its formal objections to Aptheker's scholarship, even after the Communist scholar publicly demanded release of any information pertinent to his case; he did not want "protection" from Yale. Woodward replied that, "we do not subject applicants to public exposure."101 Gaddis Smith, a professor in Yale's History Department who was hardly sympathetic to radical politics, noted that, "Although there are many faculty members who are opposed to revealing confidential information to students ... I think students 
should be privy to the full response of the department."102 If students should gain access to the departmental response, so should the applicant under consideration. Even the AHA Board offered a perplexing remark, "presentations made at meetings of the Joint Boards [where the seminar was rejected] were by individuals acting by themselves." As for the question of political discrimination against Aptheker, "we find it difficult to respond to this question. It involves either unconfessed motives or voiced considerations hidden in confidential records." 103

Indeed, the full disclosure of records would indisputably resolve both the Aptheker and Lynd cases. Just as Aptheker failed to force the Yale History's Department to open its files, I was also unable to persuade them to unlock their departmental archives. What is available in the Brewster and Woodward papers suggests political discrimination in these cases as well as some political maneuvering. Consider that the president of the historical organization that investigated the Aptheker matter wrote to Woodward in 1976: "I do hope that a sufficient number of nonradical members of the O.A.H. will attend the meeting, so that a censure motion will not pass there. If it does, we will have to go through the stupid business of sending out a ballot of the entire membership." ${ }^{104}$ What the president should have hoped for was an honest vote, regardless of political affiliation, rather than yearning for the arrival of "non-radicals." Notice also that a favorable vote for Aptheker would set in motion the democratic process of polling the membership, a procedure that was conceived of as "stupid." Are we to presume again that Woodward and the president were acting as individuals in this context?

One way that the Yale History Department might have deflected charges of political bias would have been welcoming radical Marxists onto their faculty. For instance, when historian Marvin Gettleman wrote to Woodward suggesting political discrimination against Aptheker, Woodward replied that, "we have unsuccessfully tried to interest [Marxist E. P. Thompson] in coming to Yale permanently." Gettleman confronted Woodward on this score, writing that E. P. Thompson had no knowledge of this offer and held "strong feelings about being 'used' to justify Yale's actions on Aptheker." ${ }^{105}$ Woodward backpedaled in a follow up letter and Yale's myth that it offered the socialist Thompson a permanent post was shattered.

But the New Haven historians could still stand on the ground that they welcomed the Marxist Genovese. However, Genovese was a critic of left politics, who never gained a permanent position at Yale. To his credit, Genovese differed with Yale over the Aptheker debacle, calling him a "good historian." In Genovese's characteristic vulgar language, he told Woodward, "the real bitch about Aptheker is that he was black-balled from the academic world for 30 years on straight political grounds ... The Yale Department probably made an error in judgment." ${ }^{106}$ Indeed, the History Department made an error in oppos- 
ing an appointment that was sponsored by another department. Aptheker's seminar was conducted with little fanfare, yet it illustrates the degree to which the Yale historians would go to block a radical leftist from joining their ranks, even if it was for a temporary, one-semester seminar.

While the historians failed to keep Aptheker out, they successfully blocked Lynd. In light of the evidence, we can say that Lynd's politics contributed to his academic demise. There is a certain irony, perhaps tragedy, in this tale. In April 2005 , Staughton Lynd returned to Yale University, participating in a panel with the legendary former Yale chaplain, William Sloane Coffin, and 1960s activist Michael Ferber. The panel of Vietnam era radicals found themselves again living through an equally contentious war with US troops mired in Iraq. Lynd gazed at the crowd and announced:

Most [establishment] spokespersons eventually came to condemn the Vietnam War. I recall a letter to the New York Times by the history professor who had recruited me, denouncing the massacre at My Lai in language that I found indistinguishable from that used by myself and others in the antiwar movement three or four years earlier. The problem with leaving the matter there is the following. In an intellectual community, one likes to think of ground gained as permanently possessed ... Watson and Crick discovered DNA; it does not need to be periodically rediscovered. In the matter of wars between the United States and the developing world, however, with each new war we seem to need to begin the argument all over again. ${ }^{107}$

Perhaps Lynd and the anti-war movement have failed to gain much ground in the battle over the "master narrative" that underwrites American history. Anyone who frames the Vietnam War or the invasion of Iraq as examples of the conflict between Western capitalism and its opponents is still deemed a radical. ${ }^{108}$ Revisionist historians, and activists of all stripes on the street, do not control the overall interpretation of US power, so today we "begin the argument all over again." And, Staughton Lynd remains on the frontlines of this battle, not as a distinguished Ivy League professor, but as an activist whose life with history is well lived.

I wish to thank Staughton Lynd, Jesse Lemisch, and Alfred F. Young for commenting on the manuscript and for suggesting useful sources. Howard Zinn, Daniel Rosenberg, and Jim O'Brien provided important comments and critiques. I am most grateful to Henry Abelove, John Morton Blum, and James R. Green for granting an interview regarding Lynd and Yale. 


\section{Notes}

1. Peter Novick, That Noble Dream: The "Objectivity Question" and the American Historical Profession (Cambridge: Cambridge University Press, 1991), 458-9. Novick's central concern is the historical evolution of "objectivity" among professional historians in the US and not academic repression. The nation's major historical organizations include the American Historical Association (AHA) and the Organization of American Historians (OAH).

2. Report of the American Historical Association Committee on the Rights of Historians (5 March 1974). Sheldon Hackney, a former student of C. Vann Woodward, was one of its members. The American Historical Association is "a nonprofit membership organization founded in 1884 and incorporated by [the United States] Congress in 1889," see AHA home page at <www.historians.org $>$, (accessed 20 January 2006). The AHA is a leading mainstream professional organization in the US. Frederick J. Turner, Theodore Roosevelt, Woodrow Wilson, Charles Beard, and C. Vann Woodward are among those who served as the organization's president.

3. I am not suggesting that radical historians were categorically purged from the profession. Indeed, many revisionist historians enjoyed successful careers, such as Walter LaFeber, whose The New American Empire won the acclaimed Beveridge Prize in 1962. The leading US revisionist historian, William Appleman Williams, served as president of the Organization of American Historians (OAH) in 1978, yet he confronted harassment and attacks on his scholarship throughout his career. See Paul Buhle and Edward Rice-Maximin, William Appleman Williams: The Tragedy of Empire (New York: Routledge, 1995). America's most recognizable radical historian, Howard Zinn, received tenure in political science at Boston University. In 1968 a group of radical scholars in the US formed the New University Conference. These scholars believed that "hundreds of young radicals ... who are not, like Lynd, national figures ... are being quickly fired, not hired, not promoted." See "Draft Statement of NUC Committee," NUC Newsletter, 24 (May 1968): 2.

4. History Department Letter on Lynd's qualifications, n.d., Brewster Papers, Record Unit 11, Box 139, folder 3, Yale University, Sterling Library Manuscripts and Archives. 5. Lynd, personal communication, 19 October 2005.

6. Jim O' Brien, "Be Realistic, Demand the Impossible: Staughton Lynd, Jesse Lemisch, and a Committed History," Radical History Review, v. 82 (Winter 2002): 689; Staughton Lynd, "Reflections on Radical History," Radical History Review, v. 79 (2001): 104-7; Letter from Edmund Morgan to Lynd, 2 January 1964, Kingman Brewster Papers, Record Unit 11, Box 139, folder 3, Yale University, Sterling Library Manuscripts and Archives.

7. Author's interview with Lynd, 27 April 2005. Lynd was an assistant professor of history at Yale from 1964 to 1968, Historical Register of Yale University, 1951-68 (New Haven: Yale University Press, 1969), 492.

8. Geoffrey Kabaservice, The Guardians: Kingman Brewster, His Circle, and the Rise of the Liberal Establishment (New York: Henry Holt, 2004).

9. Allan J. Matusow, The Unraveling of America: A History of Liberalism in the 1960s (New York: Harper \& Row Publishers, 1984), 11.

10. Brewster directly confronted Lynd regarding his critique of Bundy. See Lynd, letter 
to Kingman Brewster, 22 June 1965, Yale University, Sterling Library Manuscripts and Archives, Brewster Papers, Box 140, Folder 6. The liberal establishment at Yale overlapped with the US policy makers. While they often disagreed over politics, their allegiance was to the existing order, thus making them critical of those who challenged the system at its core. Information on Brewster's friendship with Bundy and government service in Geoffrey Kabaservice, The Guardians: Kingman Brewster, His Circle, and the Rise of the Liberal Establishment (New York: Henry Holt, 2004), 6, 186, 249, 348.

11. Note also that Arthur Schlesinger, Jr. and Yale's History Department chair, John Morton Blum, maintained a longtime friendship. Schlesinger drafted the notorious damage control report for President Kennedy regarding the illegal Bay of Pigs invasion. It is probably not insignificant that McGeorge Bundy, Blum and others attended cocktail parties at the Brewster home. John Morton Blum, A Life with History (Lawrence: University of Kansas Press, 2004), 96-7, 265.

12. The question as to why Yale hired Lynd in the first place is a complicated one. Lynd was widely respected for his Civil Rights work in the South, which intersected with a certain sense of noblesse oblige at Yale, a feeling that privileged liberals were obligated to help oppressed African-Americans. For example, Yale awarded an honorary degree to Dr. King in 1964 and Yale Chaplain William Sloane Coffin led Freedom Rides in the South during the early $1960 \mathrm{~s}$. Lynd arrived at Yale as it was undergoing some dramatic changes. Yale initially proposed to Lynd that he would recruit African-Americans to the university, which admitted only fourteen African-American freshmen in 1964. Information on the recruitment plan, author correspondence with Lynd, 28 April 2005; on Yale admissions, see Jerome Karabel, The Chosen: The Hidden History of Admissions at Harvard, Yale, and Princeton (Boston: Houghton Mifflin, 2005), 383. While Yale's liberals shared Lynd's enthusiasm for black equality, they consistently "work[ed] with the establishment," as Coffin explained. Kabaservice, The Guardians, 234-5. It is worth noting that before Lynd arrived in New Haven Blum complained about "political radicals," who "consumed much of his time." Two radicals, Jesse Lemisch and Norman Pollack, were particularly troublesome. Blum gladly welcomed their departure. One accepted a position elsewhere, Blum wrote, while the other "agitated for tenure," but "we did not promote him and he left." There was certain continuity in Yale's History Department regarding anti-radicalism, from Norman Pollack to Jesse Lemisch in the early 1960 s to Staughton Lynd and Herbert Aptheker shortly thereafter. See John Morton Blum, A Life with History, 183.

13. Neil Jumonville, Henry Steele Commager: Midcentury Liberalism and the History of the Present (Chapel Hill: University of North Carolina Press, 1999), 232.

14. John Morton Blum, The Republican Roosevelt, 2nd Edition (Cambridge: Harvard University Press, 2004), 2. Potter left Yale for Stanford University before Lynd's arrival: Woodward and Blum were Lynd's senior colleagues at Yale.

15. Information and quotations regarding Morgan are from Alfred F. Young, "American Historians Confront the Transforming Hand of Revolution," in The Transforming Hand of Revolution: Reconsidering the American Revolution as a Social Movement, ed., Ronald Hoffman and Peter J. Albert (Charlottesville: University Press of Virginia, 1995), 389-401.

16. On the "Big Three," Lynd's personal correspondence with author, 27 April 2005. It is important to note that Woodward's work on the conflicts between the South and the 
North presented a challenge to "consensus" history, but his liberal, anti-communism is in tune with the thrust of the liberal center. Woodward later participated in more conservative ventures, such as the National Association of Scholars. Blum quoted in John Morton Blum, A Life with History (Lawrence: University of Kansas Press, 2004), 173, 176-77. On Lynd and New Left, see "New Left Leader is a Quaker Who Teaches at Yale," New York Times, 28 December 1965.

17. Jesse Lemisch, On Active Service in War and Peace: Politics and Ideology in the American Historical Profession (Toronto: New Hogtown Press, 1975), 95. The CIA funded the Congress for Cultural Freedom and after this connection was revealed, it resurfaced as the International Association of Cultural Freedom; see Sigmund Diamond, Compromised Campuses: The Collaboration of Universities with the Intelligence Community, 1945-1955 (Oxford: Oxford University Press, 1992), 314-5.

18. John Morton Blum told me that Lynd was impeccably well-behaved in his interactions with others. Author interview of John Morton Blum, 3 November 2005.

19. David E. Rosenbaum, "House Panel Lists 'Radical' Speakers," New York Times, 15 October 1970, 23. David T. Courtwright, "Fifty Years of American History: An Interview with Edmund S. Morgan," William and Mary Quarterly, 44, no. 2, (1987): 354.

20. Quotations in this paragraph are taken from Edmund S. Morgan, "The Other Founders," The New York Review of Books, 52, no. 12, 22 September 2005, and Lynd's letter to the editor, "History from Below," The New York Review of Books, 52, no. 19, 1 December 2005. Lynd adds that Thomas Paine called for independence before Adams, Jefferson, and others, an "obvious counter-example" to Morgan's argument. Morgan's article is a review of Gary Nash's The Unknown Revolution: The Unruly Birth of Democracy and the Struggle to Create America (New York: Viking Press, 2005).

21. Jesse Lemisch, On Active Service in War and Peace: Politics and Ideology in the American Historical Profession (Toronto: New Hogtown Press, 1975), 66-74. Lemisch quotes Daniel Boorstin: "I do feel that the most effective way to fight communism is ... by helping people understand the virtues of our institutions and their special values as these emerged from history."

22. Lynd, "Remarks at the Berkeley Teach-In," 24 May 1965, Brewster Papers, Box 140, Folder 6, Yale University, Sterling Library Manuscripts and Archives.

23. Lynd's comments at a conference titled, "God and War at Yale," 28 April 2005, Battell Chapel, Yale University. Todd Gitlin, The Sixties: Years of Hope, Days of Rage (New York: Bantam Books, 1993), 266.

24. Quotations from Lynd in this paragraph are from personal correspondence with author, 28 April 2005, and Staughton Lynd, "Socialism, the Forbidden Word," Studies on the Left: A Journal of Research, Social Theory and Review, 3, no. 3 (Summer 1963): 1420.

25. Lynd quoted in John Corry, "Spokesman for the New Left," New York Times Magazine, 23 January 1966, 12.

26. Bob Moses was an early member of the Student Nonviolent Coordinating Committee (SNCC), who helped to organize voter registration projects and the Freedom Schools in Mississippi. Moses is also known as Bob Parris and became a central participant in the anti-Vietnam War movement. See Charles Payne, I've Got the Light of Freedom: The Organizing Tradition and the Mississippi Freedom Struggle (Berkeley: University of California Press, 1995), 104-29. David Dellinger was one of the chief 
organizers of the national anti-war group, the "Mobilization." Dellinger was indicted, but eventually acquitted, for his participation in demonstrations at the 1968 Democratic National Convention. Dellinger and other organizers of the protest were tried in what is known as the famous Chicago Eight trial. See Staughton Lynd and Alice Lynd, Nonviolence in America: A Documentary History, revised edition (Maryknoll, NY: Orbis Books, 2002), 397-8. The August 1968 march was organized by a group called the "Assembly of Unrepresented People" and included Lynd, Dellinger, and Bob Parris Moses. See Leaflet "Call for an Assembly of Unrepresented People in Washington, DC, August 6-9," (Grindstone Press, 1965) in Staughton Lynd Collection, Kent State University, Special Collections, Box 6, Folder 28.

27. Blum quoted in Geoffrey Kabaservice, The Guardians, 256-7. On the 1965 March, see "Capital March Stresses Vietnam instead of Rights," New York Times, 11 August 1965, 3. Staughton Lynd and Gar Alperovitz, Strategy and Program: Two Essays Toward an American Socialism (Boston: Beacon Press, 1973), 26-27.

28. The photograph from Life magazine appears in the 20 August 1965 issue with a caption describing those who threw the paint on Lynd as "right-wing extremists," 30-31.

29. John Morton Blum, A Life with History, 187.

30. Blum quoted in Jesse Lemisch, "Academic Freedom, Yale and the Aptheker Case," Newsletter of the Radical Historians Caucus, no. 22, (May 1976): 3. In Lemisch's view, Blum's "glorying in U.S. power, mission and magnificence would connect pretty directly to his desire to get rid of Staughton, whose trip to Hanoi did not glory in these things," Jesse Lemisch e-mail to author, 22 May 2005. Blum later acknowledged that in The Promise of America: "I was wrong. The book should have been more openly critical of American politics and culture than it was." See Blum, A Life with History, 173. Nonetheless, he continues "I, too, opposed the war but had no sympathy for the radical's rhetoric or methods," A Life with History, 183.

31. Woodward letter to Staughton Lynd, 19 April 1965, Woodward Papers, Box 33, Folder 397, Yale University, Sterling Library Manuscripts and Archives.

32. Lynd letter to Woodward, 16 April 1965, Woodward Papers, Box 33, Folder 397, Yale University, Sterling Library Manuscripts and Archives.

33. Clayborne Carson, In Struggle: SNCC and the Black Awakening of the 1960s (Cambridge: Harvard University Press, 1981), 107, 261-2.

34. Herndon was a black Communist arrested in 1932 for inciting an insurrection. Woodward chaired Herndon's defense fund and Herndon was released in 1936. For an excellent examination of Woodward's impatience with Communism, his gradualism and commitment to centrist politics, see Carol Polsgrove, Divided Minds: Intellectuals and the Civil Rights Movement (New York: W.W. Norton, 2001), 228-37.

35. Manning Marable, Race, Reform and Rebellion: The Second Reconstruction in Black America, 1945-1990 (Jackson: University Press of Mississippi, 1991), 83-4. Marable cites the 1974 edition of Woodward's book.

36. Staughton Lynd, Intellectual Origins of American Radicalism (New York: Vintage Books edition, 1969), 7, and Staughton Lynd "A Radical Speaks in Defense of SNCC," New York Times, 10 September 1967, 271.

37. Staughton Lynd, Intellectual Origins, 7.

38. Howard R. Lamar letter to Staughton Lynd, 18 March 1968, Wisconsin Historical Society, Archives Reference, Staughton Lynd Collection, Call Number M91-129, Box 
24, Folder 4: "Lynd/Yale Personal File."

39. Charles A. Barker, "Review of Intellectual Origins of American Radicalism," Journal of American History, 55, no. 3 (December 1968): 634.

40. Eugene D. Genovese, "Abolitionist," The New York Review of Books, 11, no. 5, 26 September 1968. Woodward letter to Howard Lamar, 29 April 1968, Woodward Papers, Box 62, Folder 746. Yale University, Sterling Library Manuscripts and Archives.

41. Nash categorizes Genovese's review of Lynd's books as "vicious, sectarian," see Gary B. Nash, "Class in Early American History: A Personal Journey," Labor: Studies in Working-Class History of the Americas, 1, no. 1 (Winter 2004): 19-22. See also Lynd's reply to Genovese in Staughton Lynd, "Self-Evident Truths?" The New York Review of Books, 11, no. 11 (December 1968). Zinn quotation, personal correspondence with author, 6 November 2005.

42. David Donald, "New Left History," Commentary, August 1968, 78-9.

43. Eugene Genovese letter to Woodward, 7 April 1976, Woodward Papers, Box 85, Folder 1, Yale University, Sterling Library Manuscripts and Archives.

44. This observation is derived in part from a reading of James Livingston, "Marxism and the Politics of History: Reflections on the Work of Eugene D. Genovese," Radical History Review, no. 88 (Winter 2004): 30-48.

45. Genovese quoted in Peter Kolchin, "Eugene D. Genovese: Historian of Slavery," Radical History Review, no. 88 (Winter 2004): 62. Lynd, Intellectual Origins, vi. My comments on Genovese's scholarship in this paragraph follow Kolchin's article.

46. Howard Lamar letter to Dean John Miller, 8 March 1968, Woodward Papers, Box 62, Folder 746; Woodward letter to Howard Lamar, 29 April 1968, Woodward Papers, Box 62, Folder 746, Yale University, Sterling Library Manuscripts and Archives.

47. I am in no way suggesting that Yale dismissed Lynd to make funds available for Genovese's appointment as the money came from the Council on Comparative and European Studies.

48. Statement by Kingman Brewster, Jr., 18 January 1966, Brewster Papers, Box 138, folder 12, Yale University, Sterling Library Manuscripts and Archives.

49. John Prados, "40th Anniversary of the Gulf of Tonkin Incident," 4 August 2004, $<$ http://www.gwu.edu>, accessed on 5 June 2005. Marilyn Young, The Vietnam Wars, 1945-1990 (New York: Harper Perennial, 1991), 116-23.

50. William Buckley, Jr., “The Profs Trip," Providence Journal, 19 January 1966.

51. John Stewart letter to Kingman Brewster, Jr. in Brewster Papers, Box, 138, Folder 14. Yale University, Sterling Library, Manuscripts and Archives.

52. See John Castles "Suggested Lynd Reply 2/1/66" and "One Agent's First Letter," in Brewster Papers, Box 138, Folder 12, Yale University, Sterling Library Manuscripts and Archives. There were also letters in support of Lynd, but the preponderance of letters denounced him.

53. Alumni comments taken from letters to Alumni Magazine and the Graduate Fence filed in Brewster Papers, Box 138, Folder 12, Yale University, Sterling Library Manuscripts and Archives.

54. John Castles letter to Kingman Brewster, Jr. in Brewster Papers, Box 138, Folder 12 , Yale University, Sterling Library Manuscripts and Archives. The "first batch" of replies to the Castles form letter to alumni include a letter that stated, "I had five letters from classmates who have refused to make contributions to Yale as long as Lynd is associated 
with the University ... it is certainly going to effect the fund." Charles Munson, Letter to John Castles, 10 February 1966 in Brewster Papers, Box 138, Folder 16, Yale University, Sterling Library Manuscripts and Archives. Another letter stated "I have already received many unfavorable comments regarding Lynd and his trip to Hanoi...I am sure you realize that many of the alumni are becoming disenchanted with our efforts to raise money," see John M. Brown, Jr., letter to John Castles, 9 February 1966, Brewster Papers, Box 138, Folder 16, Yale University, Sterling Library Manuscripts and Archives.

55. Brewster to Castles, 10 January 1966, Brewster Papers, Box 138, Folder 12. Yale University, Sterling Library Manuscripts and Archives.

56. Letter from John M. Blum to Dean Georges May and Mr. Henry Chauncey, Jr., Special Assistant to the President, 15 April 1966, Brewster Papers, Box 138, Folder 12, Yale University, Sterling Library Manuscripts and Archives. Blum met with Lynd after he took part in a teach-in in England to discuss a Yale rule concerning the number of days a week that a teacher must be on campus. Blum acknowledges that he never informed Lynd of this rule up to this point and that Lynd had not missed any classes as he scheduled his teaching on simultaneous days.

57. I presented this letter to Blum and he guessed that he was explaining himself in the letter. Author interview with Blum, 3 November 2005. However, the letter to Dean May discussed "questions that have arisen about the activities" of Lynd, including the "content" of his Ottawa speech. It is unlikely that Blum was explaining himself when he discussed the content of a speech given by Lynd, which he adds was "strident." It is also rather curious that a US Ambassador provided Lynd's speech to Yale's president. See Blum, $A$ Life with History, 183-4.

58. James R. Green, Taking History to Heart: The Power of the Past in Building Social Movements (Boston: University of Massachusetts Press, 2000), 26. Green explained that the graduate students could not prove that Lynd was a victim of political bias, but some of them still believed that Lynd was treated unfairly because of his radicalism; author interview with James Green, 1 November 2005. Henry Abelove, also a member of the graduate student investigation, believed that our "professors were angry at us for calling for an investigation ... Woodward was particularly angry." According to Abelove, Woodward said that if Lynd "proves to be a Gibbon, he can get tenure." Author interview with Henry Abelove, 29 November 2005.

59. Letter from John Ecklund to Kingman Brewster, Brewster Papers, 28 September 1967, Box 140, Folder 5. Yale University, Sterling Library Manuscripts and Archives.

60. In the opinion of one alumnus, Lynd "saw the handwriting on the wall ... I passed this information on to some of my reluctant classmates as a sign that Yale was getting back on the proper road, and I immediately received gifts from men who told me they would never give another cent"; John Stewart, letter to Kingman Brewster, 8 June 1967, Brewster Papers, Box 138, Folder 14, Yale University, Sterling Library Manuscripts and Archives.

61. "The People of the State of Illinois; Cook County Teachers Union, American Federation of Teachers and Staughton Lynd v. Board of Governors of State Colleges and Universities," Brief of Amicus Curiae in Opposition to Defendants' Motion to Dismiss, Circuit Court of the Seventh Judicial Circuit, Sangamon County Illinois, in Thomas Emerson Papers, Box 9, Folder 131, Yale University, Sterling Library Manuscripts and Archives. 
62. Byrd's comments in "History Professor Lynd Paid Penalty for Antiwar Activities," St. Louis Post Dispatch, 24 September 1967, 8H. Student remarks appeared in “Outstanding Professor," Chicago Sun Times, 4 September 1967 in a letter signed by Alice Carnes and over 25 others.

63. Quotations from, and details about, the board's public admission that Lynd's politics led to his dismissal in, The Committee for Academic Freedom in Illinois, "The Staughton Lynd Case-A Fact Sheet," 29 August 1967, in Woodward Papers, Box 88, Folder 54, Yale University, Sterling Library Manuscripts and Archives. In all, five colleges overturned appointments to Lynd. They are Chicago State College, University of Illinois, Northern Illinois University, Roosevelt University, and Loyola University.

64. From 1970-73, Young served on the American Historical Association Committee on the Rights of Historians, a body that he helped to form. See Alfred F. Young, "American Historians Confront the "Transforming Hand of Revolution,'" in The Transforming Hand of Revolution: Reconsidering the American Revolution as a Social Movement, ed. Ronald Hoffman and Peter J. Albert (Charlottesville: University of Virginia Press, 1995), 432-33.

65. Information on the lawsuit from author's personal correspondence with Lynd, 9 June 2005. The suit was settled in fall, 1967. Information on the lawsuit was readily available in newspaper accounts, such as "Lynd plans to Sue on Refusal of Job at Chicago College," New York Times, 2 August 1967.

66. Douglas P. Woodlock, "Blum says Lynd's Chances Minuscule because of Budget," Yale Daily News, 28 September 1967.

67. Woodlock, "Blum says Lynd's Chances Minuscule because of Budget," Yale Daily News, 28 September 1967.

68. Letter from Staughton Lynd to John Blum, 10 September 1966, Wisconsin Historical Society, Staughton Lynd Collection, call number M91-219, Box 24, Folder 4: "Lynd/Yale."

69. Letter from John M. Blum to Staughton Lynd, 13 September 1966, Wisconsin Historical Society, Staughton Lynd Collection, call number M91-219, Box 24, Folder 4: "Lynd/Yale."

70. Woodlock, "Blum Says Lynd's Chances Miniscule because of the Budget," Yale Daily News, 28 September 1967.

71. Blum, A Life with History, 185. I wish to thank Jesse Lemisch for bringing Blum's remarks here to my attention.

72. I wish to thank Judith Ann Schiff, Chief Research Archivist, Yale University Manuscripts and Archives, who verified the date that Blum left the chairmanship with the Yale Office of Institutional Research; email to author, 11 October 2005.

73. Woodlock, "Blum Says Lynd's Chances Miniscule because of the Budget," Yale Daily News, 28 September 1967. While Blum decisively announced the budget constraint, he reports that he never told Lynd of the new budget, nor does he feel that anyone at Yale had a responsibility to tell Lynd about the budget change; author interview with John Morton Blum, 3 November 2005.

74. Blum, A Life with History, 185. It is worth noting that the graduate committee that investigated the Lynd affair also questioned Blum's presentation of the budget. "We do not feel that financial considerations can be said to be absolutely decisive as Professor 
Blum originally told you they were." See James R. Green (for the Committee), letter to Staughton Lynd, 11 January 1968, Wisconsin Historical Society, Staughton Lynd Collection, call number M91-219, Box 24, Folder 4: "Lynd/Yale." Green later noted that the budget restriction was a "dubious rationale," author interview with James Green, 1 November 2005.

75. Staughton Lynd, "Academic Freedom: Your Story and Mine," Columbia University Forum (Fall 1967): 26.

76. Edmund S. Morgan and C. Vann Woodward, "Academic Freedom: Whose Story?," Columbia University Forum (Spring 1968): 42. I informed Blum that Lynd said he was never told that the budget constraint was lifted and he replied that Lynd was probably telling me the truth, author interview with John Morton Blum, 3 November 2005.

77. Letter from Henry Chauncey, Jr. to Mr. John Seifert, 18 October 1967, Brewster Papers, Box 138, Folder 13, Yale University, Sterling Library Manuscripts and Archives. 78. Blum also says in his memoir that tenure safeguards free expression, "which otherwise would be susceptible to threats from alumni." Note that Lynd would have benefited from protection from alumni threats. Furthermore, Blum describes his understanding of Yale's tenure process: "we required ... American historians to have published at least two books." Blum, A Life with History, 180. When Lynd's tenure was rejected in March 1968, he had published four books: Anti-federalism in Dutchess County, New York; NonViolence in America; Class Conflict, Slavery and the United States Constitution: Ten Essays; Intellectual Origins of American Radicalism.

79. James Green, "Debate: American Radical Historians on their Heritage," Past \& Present, no. 69 (November 1975): 126.

80. Charles A. Barker, "Review of Intellectual Origins of American Radicalism," Journal of American History, 55, no. 3 (December 1968): 634.

81. James R. Green (for the Committee), letter to Staughton Lynd, 11 January 1968 and Staughton Lynd, letter to James Green, 18 January 1968 in Wisconsin Historical Society, Staughton Lynd Collection, call number M91-219, Box 24, Folder 4: "Lynd/Yale."

82. Author interview with James R. Green, 1 November 2005. Green, Taking History to Heart, 26.

83. History Department Letter on Lynd's qualifications, n.d., Brewster Papers, Record Unit 11, Box 139, folder 3, Yale University, Sterling Library Manuscripts and Archives. 84. Dale Noble letter to Howard Phelan, 13 July 1967, Brewster Papers, Record Unit 11, Box 140, folder 5, Yale University, Sterling Library Manuscripts and Archives.

85. Edward Thompson, "Preface" in Staughton Lynd, Class Conflict, Slavery and the United States Constitution: Ten Essays (New York: Bobbs-Merrill, 1967), ix-xiii.

86. Edward Countryman, The American Revolution, revised edition (New York: Hill and Wang, 2003), 237, 258.

87. Winks quoted in Thrity Umrigar, "Fighting the Good Fight: Niles, Ohio is a long way from Yale, but ' 60 s radical Staughton Lynd hasn't given up on the dream,' Sunday Beacon Magazine, 22 November 1998, 7.

88. Howard R. Lamar letter to Staughton Lynd, 18 March 1968, Wisconsin Historical Society, Archives Reference, Staughton Lynd Collection, Call Number M91-129, Box 24, Folder 4: "Lynd/Yale Personal File."

89. Staughton Lynd, "Revisiting Class in Early America: Personal Reflections," Labor: Studies in Working-Class History of the Americas, 1, no. 1 (Winter 2004): 31-4. 
Biographical information in Staughton Lynd, Living Inside Our Hope, (Ithaca: Cornell University Press, 1997), 26.

90. Abigail Fuller, "Producing Radical Scholarship: The Radical Sociology Movement, 1967-1975," Sociological Imagination, 33, no. 1 (Fall 1997). Lemisch, On Active Service in War and Peace, 45, 118-119.

91. To avoid misunderstanding, many radical scholars gained academic employment and even acclaim, but this fact does not erase the harassment faced by many others. See footnote 3 above regarding the Report of the American Historical Association Committee on the Rights of Historians, 5 March 1974 on the mistreatment of left historians. One reason why radical historians gained acceptance arises from what Novick calls "restriction through partial incorporation." He cites an issue of Radical History Review that featured interviews with "eight of Americas leading leftist historians." Novick claims that none of them suggested that Marxism was a "sufficient method or worldview"; Novick, That Noble Dream, 459-61. Jim O' Brien observes that the "real trend in the 1970s was cooptation, not combat. So well did some radical historians master the techniques of scholarly writing that the 'mainstream' of academic history broadened to include them." See O' Brien, "Notes on the Search for a Democratic History," Radical Historians Newsletter, no. 86-87 (December 2002). Staughton Lynd suggests that academia encourages radicals to make concessions, "the university corrupts radicals more often than it destroys them." See Staughton Lynd, "Intellectuals, the University and the Movement," The Journal of American History, 76, no. 2 (September 1989): 480. One "concession" that many radical historians made is to accept the boundaries of academic mores, a social code that discourages structural analysis regarding the inherent flaws in the capitalist system. Lynd's work opposes the grand narrative head-on and is likely one reason why he confronted academic hostility. As Christopher Lasch observes, "radical historians came to be admitted as partners in the scholarly enterprise ... when they signified a willingness to observe prevailing conventions and write books that were just as narrow [and] tedious" as the mainstream. Consider that Howard Zinn's A People's History of the United States, which sold some one million copies, ignores prevailing conventions and the narrowness of many scholarly monographs. Zinn directly challenges the capitalist grand narrative; this approach might explain both the book's popularity outside the historical profession and his inability to gain tenure in a formal history department. On Lasch's remarks see, "Consensus: An Academic Question," Journal of American History, 76, no. 2 (September 1989): 458.

92. The quotation is from Yale Political Science Professor, Joseph LaPalombara in "The Aptheker Case: "Massive Attack in a Minor Appointment"' Yale Alumni Magazine (February 1976): 29-31. Aptheker was rejected by approximately 50 US colleges and taught at Hostos Community College in the Bronx, New York; see Lemisch, On Active Service in War and Peace, 118 for information on Aptheker and other cases concerning the political discrimination against radical scholars.

93. "The Yale-Aptheker Issue," Yale Historical Bulletin, no. 25 (December 1976). Jesse Lemisch, Marv Gettleman, John Bracey, Martin Duberman, Michael Frisch and Sterling Stuckey, "A Statement in Support of the Resolution," Organization of American Historians Newsletter, 4, no. 1 (July 1976): 4-5.

94. My account of Aptheker's situation follows that of Jesse Lemisch, "If Howard Cosell can Teach at Yale, Why Can't Herbert Aptheker?" Newsletter of the Radical Historians 
Caucus, no. 22 (May 1976): 1-9. "The Aptheker Case," Yale Alumni Magazine, (February 1976): 29-31. Cully Irving, "Aptheker Responds to Attacks on Professional Qualifications," Yale Daily News, 11 February 1976.

95. Herbert Aptheker, "Aptheker Speaks: 'I Need no Protection," Yale Daily News, 30 January 1976.

96. Woodward also opposed the establishment of a black student center at Yale, telling

Kingman Brewster: "May I put in a word of unsolicited advice about the proposal to establish a black student center on the campus? ... In my opinion the whole movement of black separatism is a reaction against the shock of white competition. Segregation has protected them from competition for generations. Southerners were not wholly hypocritical in saying that the Negroes preferred Jim Crow. Separatism is a militant stance but a defensive reaction - in effect a regression to the old way of dealing with competition ... But if a black student center is established I am afraid it will be very hard to get rid of it after the temporary need has disappeared. It could become the source of endless trouble." See C. Vann Woodward letter to Kingman Brewster, Jr., 4 March 1968, in Woodward Papers, Box 62, Folder 749, Yale University, Sterling Library Manuscripts and Archives.

97. Lemisch, "If Howard Cosell can Teach at Yale," Newsletter of the Radical Historians Caucus, no. 22 (May 1976): 1-9. "The Aptheker Case," Yale Alumni Magazine, (February 1976): 29-31. Cosell, a popular television broadcaster, taught a seminar on "Big Time Sports."

98. Ramy Djerassi, “Aptheker at Yale," Yale Daily News, 11 February 1976.

99. Jonathan Kaufman and Andrew Pincus, "History faces Probe on Aptheker," Yale Daily News, 13 October 1976. Jesse Lemisch rallied to bring the matter before the OAH, see Editorial Collective, "Southern History and the Politics of Recent Memory: Responses to the C. Vann Woodward Interview," Radical History Review, no. 38 (1987): 151.

100. "Yale-Aptheker Inquiry Concluded," American Historical Association Newsletter, 16, no. 2 (February 1978): 1.

101. C. Vann Woodward, "Letter to the Editor," Yale Daily News, 2 February 1976. Aptheker, "Aptheker Speaks: 'I Need no Protection," Yale Daily News, 30 February 1976.

102. Smith quoted in "The Aptheker Case: 'Massive Attack on a Minor Appointment,"” Yale Alumni Magazine, (February 1976): 31. On Smith and radical historians, he places William Appleman Williams and Gabriel Kolko at "the forefront of revisionist scholars," but they are "essentially pamphleteers." See Gaddis Smith, "The United States as a Villain," The New York Times, 10 October 1976, 250.

103. "Yale-Aptheker Inquiry Concluded," American Historical Association Newsletter, 16, no. 2 (February 1978): 1.

104. Frank Freidel letter to C. Vann Woodward, 2 April 1976, Woodward Papers, Box 85, Folder 1, Yale University, Sterling Library Manuscripts and Archives.

105. C. Vann Woodward, letter to Marvin Gettleman, 23 February 1976. Marvin Gettleman, letter to C. Vann Woodward, 29 March 1976. Woodward Papers, Box 85, Folder 1, Yale University, Sterling Library Manuscripts and Archives. After Gettleman challenged Woodward's assertion about Thompson, Woodward sent a carefully worded letter that states, "The name E.P. Thompson should certainly not be allowed to enter into 
this or any other public discussion of appointment policy at Yale." Gettleman's letter claims that Woodward already shared the notion that Thompson was offered a permanent post at Yale with others, thus it was Woodward who allowed Thompson's name to improperly enter the public realm. See Woodward letter to Gettleman, 4 April 1976 and Woodward, Letter to James Green, 15 March 1976, Woodward Papers, Box 85, Folder 1, Yale University, Sterling Library Manuscripts and Archives. Dorothy Thompson, the late E.P. Thompson's wife, recalls that "Edward was certain that he had never been offered any sort of post at Yale ... There was certainly never any straightforward offer from the department," personal correspondence with author, 27 October 2005.

106. Eugene Genovese letter to Woodward, 7 April 1976; Eugene Genovese letter to Woodward, 23 April 1976 in Woodward Papers, Box 85, Folder 1, Yale University, Sterling Library Manuscripts and Archives.

107. Staughton Lynd, "The Two Yales," Remarks at the "God and War at Yale" Conference, 28 April 2005, Battell Chapel, Yale University.

108. I am paraphrasing William Appleman Williams, The Tragedy of American Diplomacy (New York: W.W. Norton, 1972), 10. 